\title{
Prophecy in William Blake's The Marriage of Heaven and Hell
}

\author{
Baoguo Shen \\ Baoding University, Hebei, China \\ Yinxia Liu \\ Baoding University, Hebei, China \\ Junxia Yang \\ Baoding University, Hebei, China
}

\begin{abstract}
William Blake is a famous English poet and engraver, one of the leading poets of the pre-romantic period. Many critics consider him as a remarkable poet, prophet, philosopher and artist in the world. He was unknown during his lifetime and was often called a madman. Many people surprisingly find that Blake has depicted the life in modern time in his poems and pointed out the prospects. The Marriage of Heaven and Hell is a classical prophetic book, which shows Blake's gift of prophecy. The thesis will deal with Blake's prophecy in The Marriage of Heaven and Hell from the perspective of contradiction, vision and imagination. William Blake's prophecy includes the destruction of empire and Jerusalem's reconstruction.
\end{abstract}

Index Terms-William Blake, prophecy, The Marriage of Heaven and Hell

\section{INTRODUCTION}

The Marriage of Heaven and Hell is one of those prophetic books written by the poet William Blake. In this work Blake expressed his own revolutionary thought and Romantic ideas in form of biblical prophecy. The poem was composed among 1790-1793, during which the French revolution is widely carrying on. And Louis XVI was put to death January in 1791, then Britain declared war on France a year later. So Blake has a personal experience and distant observation and deep insight on the violate revolution, and all of which are reflected in The Marriage of Heaven and Hell. The book consists of five chapters: the argument, the voice of the devil, a memorable fancy, proverbs of the hell, a song of liberty. The first two parts could recognized as the prude of the poem, and the voice of the devil and a memorable fancy can be seen as the formal performance, then last two are the curtain falls.

Blake lived and worked in London. The social and political changes in London at that time had great impact on his writing. But for quite a long time, Blake's reputation floundered. Modern scholars study William Blake's works mostly according to Geoffrey Keynes's A Bibliography of William Blake (Bloom, 1976, p.47). S. Foster Damon's pioneering William Blake: His Philosophy and Symbol argued that Blake's major prophecies, sometimes thought to be incomprehensible or the product of an irrational mind could be interpreted through a systematic research of his use of symbol. (www.duke.edu) In the year of 1947 Zhang Zhiheng(1989) regarded William Blake as one of great giants in English literature for his prophetical imagination and mythic structure. In Frye's hands, Blake's system does not even require the outside reference of mystical experience and is actually carefully organized in its structure of expanding frameworks of interpretation. G. E. Bentley's Blake Records carefully records all known evidences about Blake's life, including contemporary accounts of him. Among the numerous explications of Blake's poetry that followed, Harold Bloom's The Visionary Company and Blake's Apocalypse influenced many critics in the reading of his individual poems.

However, domestic Blake's studies seem deficient and no important thesis has covered his The Marriage of Heaven and Hell yet. And the majority of the researchers put their emphasis on the analysis of cultural meaning and religious ethics by artistic perspectives, which ignores the prophecy itself. It is my hope to enrich former findings while opening up some new perspectives which former researches have not pursued. Thus this study focuses on the embodiments of The Marriage of Heaven and Hell by the theory of prophecy. Blake predicts the destruction of empire and Jerusalem's reconstruction through the prophetic methods of contradiction, vision and imagination. Today Blake is now recognized as one of the most original and challenging figures in the history of English literature.

\section{THE THEORY OF PROPHECY}

Prophecy is a process in which one or more messages that have been communicated to a prophet are then communicated to others. Such messages typically involve divine inspiration, interpretation, or revelation of conditioned events to come as well as testimonies or repeated revelations that the world is divine. The process of prophecy 
especially involves reciprocal communication of the prophet with the source of the messages. Various concepts of prophecy are found throughout all of the world's religious and cults. To a certain degree prophecy can be an integral concept within any religion or cult. The term has found deep usage in the Abrahamic religious, including Judaism, Christianity, Islam, Baha's and Mormonism along with many others.(http://en.wikipedia.org/wiki/Prophecy) The thesis below talks about two aspects of prophecy including origin and historical developments.

The English word prophecy came from Old French profecie about 1225. Its meaning is the person who has the gift to interpret the will of the gods. Gradually in Greek the word prophecy means to say something beforehand.

In Chinese history prophecy played an important role in the ancient society. It was originated from mysterious thinking and closely related with primitive religion. Witches had special identities between heaven and earth, and they used a variety of witchcraft, astrology to predict the future. Jiang Ziya, a famous predictor Chinese history, made a great contribution to building Shang Dynasty by using his prophetic abilities and military strategies. His poetical book Wan Nian Ke predicts the changes of China from Zhou Dynasty to the Glorious Harmonious World.

Zuozhuan, a famous book written in Spring and Autumn period in ancient China, permeated with prophetic features. The Spring and Autumn period was a notable reform period. In that time, both the magic and rationalistic activities prevail in such a period. The prediction was frequently used when people talked about nature, heaven, spirit, luck and disaster, augury and dream and they put forward all kinds of forecast and the future development. The Spring and Autumn period became a prophetic times when people are so confident and impulsive to make prophecies, therefore we could see such a large number of prophecies in Zuozhuan. It includes including horoscopy, oneiromancy, divination, face reading and so on The prophecies not only represent the mystery of predictions but also reflect the evolution of thought in the frame of rational thinking. Ma Qian Ke is another famous prophetic book by Zhuge Liang, the counselor of Country Shu in the Three Kingdoms period. He wrote down the lessons in the army in my spare time. The book forecast most of the historic events that would happen in China from Three Kingdoms period to the foundation of Republic of China. TuiBei Figure is one of the most famous prophetic book in Chinese history. It was composed by Li Chunfeng during the Tang dynasty. The book predicts the future of social changes from Tang dynasty to the glorious harmonious world. Each poem with a figure in the book represents a change of dynasty.

In a remote period of Greek history, the ancient Greeks often ask the Oracle or find answers to the problems threatened to their real life. In the ancient Greek city-state political life, Oracle was also a very powerful influential way of citizens' lives. They found prophecies from the sacrifice, birds, dreams and any other things. More importantly, they asked the Oracle. There are many oracle temples in Greece. Delphi was the most famous one. Apollo in Delphi became the divine founder around 800 B.C.. Delphi had become an oracular center of the ancient Greek world gradually, and its prestige continued during the entire golden era of Hellenic culture. Originally the oracle could only be consulted once a year on the 7th of Bysios, and this restriction was only removed at a late period when consultation once a month was allowed, except three months when Apollo leaved Delphi in winter. The procedure of the oracle was restricted strictly. Apollo's priestess and enquirers must obey the special procedure during consulting the oracle. The tripod, sacred spring and laurel are necessary things. Pythia give oracles in form of poetry and prose.

Holy Scripture accepted as Word of God, is believed as the text dictated by different authors in God's call. A Hebrew prophet is the spokesperson of God. Bible is permeated with prophecies. Furthermore there are a thousand specific prophecies. It contains the natural disasters, Israel's fate in the future, the coming of the messiah. The Bible prediction contains many species and covers large time span. Most of the prophecies in the Bible have come true accurately. Prophets through the words of God foretell the fate of a person, the life of a nation, prosperity of a city, and the replacement of countries over a time from that time to a thousand years later. A recognized form of Christian prophecy is the prophetic drama and a metaphorical relationship between present situations and future events. In the Old Testament prophets are concerned about the crisis that they face at that time. And they are associated with the realities of the contemporary society. The prophets are described as real person. They fight for the rights, justice, defense, glory, freedom and social morality. In The New Testament, Prophecy is one of the spiritual gifts, and the prophets are the ones who have supernatural abilities and could receive the information from God. And they convey the message of God to save the kind people and punish the enemies. There are instances in the Gospels where individuals are described as being prophets. Jesus foretells his death and resurrection.

\section{Blake's Prophetic Methods in The Marriage of Heaven and Hell}

The prophetic methods of contradiction, vision and imagination are the main methods for William Blake to express his prophecy. Blake uses the contradictory ideas "without contraries is no progression" to predicts the development of human society. The experience is an indispensible step to achieve one's goals. And the society is composed of people. So only the contradictory power of innocence and experience effect on the society can the society develops and evolves. In addition, he also employs his fourfold vision and imagination to predict the coming of a new world. In this new world humanity achieves liberation from the tyranny of church.

\section{A. The Prophetic Method of Contradiction}

William Blake employs the specific people and thing in the physical world to express his philosophy of contradiction, which is vividly embodied in his prophetic poems. In The Marriage of Heaven and Hell, he puts forward "without 
contraries is no progression, attraction and repulsion, reason and energy, love and hate, are necessary to human existence" (Blake, 1975, p.15). Here Blake is saying that without things to contrast each other one cannot progress. That is the law of development applied to human development. And also it is the prophecy that Blake has expressed.

In The Marriage of Heaven and Hell, Blake switches the values heaven and hell represent around, so angels have negative connotations and the devil connotations. So as it is in the real world. During his times, the majority of the intellects praised the achievements revolution had brought in. Actually people only find one aspect in the world. While Blake employs the contradiction to predict the law of human development, the revolution will inevitably bring good and evil. Blake has established his basic tone for all the poems in that collection in Songs of Innocence. It is supposed to be full of joy and pleasure. He depicts a perfect world in the children's eyes and expresses the writer's inner feelings. Love and hate energy and reason, innocence and experience, are components that belong to his framework of the contrary states of the human soul. Through the anatomy of these states in his Songs of Innocence and Experience, Blake is able to prophesy the advent of a new age when God manifest in man and the natural spontaneous acts of man instinctively create a world of love and freedom. In such a world, the seeming evils of climate, disease, and death are rendered painless by the inner strength of faith. This belief is the moral basis upon which the reconstruction of Jerusalem must build.-It is also the basis to which his view of body and soul is attached.

While In Songs of Experience, Blake has established the social reality, which is the opposite of Innocence. Combining Songs of Innocence with Songs of Experience, same titles reflect contrary meanings. So Blake thinks that God created the world and endowed the equality to it. He created lamb and tiger at the same time. So people can not simply think that the tiger is definitely the evil and the lamb is good, innocence and experience also apply to it. Behind the experience there is energy and illiteracy exists in the innocence. They are all contradictory power, necessity of survival and the condition of progressing. Here Blake predicts that the experience is an indispensible step to achieve one's goals. And the society is composed of people. So only the contradictory power of innocence and experience effect on the society can the society develops and evolves.

\section{B. The Prophetic Method of Vision}

William Blake puts the competence of poem or creativity and prophecy in the same important position. Those who are of competence in having a deep insight of the real life of things in the world and can predict eternity. And this kind of competence is called vision. He predicts a new world through the prophetic method of vision which is also called his visionary world. And he divides his visionary world into different worlds:

Now I a fourfold vision see,

And a fourfold vision is given to me

This fourfold in my supreme delight

And threefold in soft Beulah's night

And twofold always. (Glen, 1983, p.25)

Here Blake describes different levels of imaginative perception. While we must always reject the single vision of the scientists and cultivate twofold vision. There are other levels of perception which enable us to envisage an earthly paradise; the threefold vision comes to us in dreams and the fourfold vision vouchsafes a glimpse of the supreme unity of heaven. In The Marriage of Heaven and Hell, for example, the threefold vision creates a union of rationality and imagination. The result is that we get a glimpse of an earthly paradise. Actually Blake is predicting a new world, and in this new world humanity achieves liberation from the tyranny of Church and Stale. Crucially, Blake believed it was insufficient to rely on the eye to see the world as the scientists and materialists. Qian Qing (2006) said the eye was a useful tool but insufficient unless working in combination with the creative imagination which could transform mere sensory impressions and conjure up the visionary levels. And the fourfold vision is the supreme insight which reconciles all of the other levels offering an almost mystical insight into the nature of the cosmos. The point is made in the wonderful lines which open the poem entitled Auguries of Innocence. The Imagination, says Blake, can help us:

To see a world in a grain of sand

And a heaven in a wild flower,

Hold infinity in the palm of your hand

And eternity in an hour. (Blake, 1976, p.25)

In Songs of Innocence there is a repeated pattern in which the poet's perception first sees then transforms the material world (twofold vision), then projects an earthly paradise watched over by a loving God (three-fold vision) while conceiving the whole in terms of a mystical joy immanent throughout the universe (four-fold vision). An understanding of this, of course, also helps us by contrasts to come to terms with the evils and corruptions of the fallen, rationalist and materialist world described in Songs of Experience.

\section{The Prophetic Method of Imagination}

Blake's idea of imagination stems from his political and religious radicalism, with reason as the core target. The social realities disillusion his belief that human beings can be liberated through revolution, and he comes to realize that the true freedom of man is spiritual. Yet man's mind is restricted by churches and the falsity of reason. Through attacking churches that exploit human beings in this universe, Blake is completely convinced that imagination is true means of perceiving this world. Besides, Blake holds that man's true state is imaginative. Possessing imagination, 
human beings in the state of experience could see the divinity, which in turn could liberate their lapsed souls.

To Blake, imagination is not a state but is human existence itself. Imagination is the faculty whereby Blake sees into the reality of things. This is Blake's definition of Imagination. This imagination, Wang Zuoliang (1991) described in his History of English Romantic Poems, which sees the truth of the infinite inner life of the human, is the eternal body of man as well as god himself (p.22). It is best manifested in the works of art, which Blake termed as Poetic Genius. Like imagination, Poetic Genius is not bound by experience; but instead, through its vision, its renders' experience infinite. Poetic Genius is the true man; it applies its unchangeable power of imagination to changeable objects or environments. Being conscious of the difference between imagination and natural memories, what is eternal and what is changeable gives birth to an image of truth. The vision of this truth scatters the clouds of reason and gives creative energy to man. In The Marriage of Heaven and Hell the weak in courage is strong in cunning. Though depending on the energies of the other men, the weak priests shows they are superior to the active men by denigrating the importance of human energy and productive work. Further, they try to associate their power with an incomprehensible supernatural source. By claiming they are carrying out God's commands, the priests make the strong active men believe whatever they do is definitely right.

\section{The Embodiments of Prophecy in The Marriage of HeAven ANd Hell}

William Bake employs the prophetic method contradiction, vision and imagination to predict the destruction of empire and Jerusalem's reconstruction. The empire is not specific but abstract. That is the religious empire and the empire of combination of industrial revolution and machines. The machine is the slave of people created, also the tolerate monarch. Then Blake predicts the coming of new age.

\section{A. The Prophecy of Destruction of Empire}

In the prelude Blake tracks the essence of value of good and evil twisted by the religion trying to thoroughly change people's value of good and evil. At the same time he declares the unity of body and soul as well as the new value of good and evil. Those positive, creative and authentic acts are good, which promote the progress of human being. However those acts of negative effects and blocking others are evil, which lock up the development of human beings. So the combination of the background of The Marriage of Heaven and Hell and the poems itself can indicates the destruction of the empire. So in the argument:

Rintrah roars shakes his fires in the burden'd air;

Hungry clouds swag on the deep. (Blake, 1975, p.35)

Rubtrah is prophet and his anger indicates that big change is coming. Here the hungry clouds symbolize the impetuous air of and the greedy desire. In the last part a song of liberty, the son of fire was also called the new terrorist and the new miracle, which is the sun in Blake's heart. Before he was born:

The Eternal Female groan'd! it was heard over all the Earth;

Albions coast is sick silent; the American meadows faint!

Shadows of Prophecy shiver along by the lakes and rivers and mutter across the ocean.

France rends down thy dungeon;

Where the son of fire in his eastern cloud, while the morning plumes her Golden breast, Spurning the clouds written with curses, stamps the stony law to dust, loosing: the eternal horses from the dens of night, crying, Empire is no more! And now the lion wolf shall cease. (Blake, 1975, p.66)

This is the religious empire and the empire of combination of industrial revolution and machines. The machine is the slave of people created, also the tolerate monarch. And we increasingly use it then we become dependent on it. The progress of industrial civilization didn't bring in happiness, and we are still bound, but the empire will be destroyed.

\section{B. The Prophecy of Jerusalem's Reconstruction}

To a certain degree, Blake's The Marriage of Heaven and Hell is the manifesto of his view of contradiction and vision. One of the most striking features of The Marriage of Heaven and Hell is the complexity of allegorical images, including those of angels, devils, animals, as well as fire and flame. They are intentionally used to build a dual world, in which two opposites exist contrarily. They are symbolically used to argue for a prophecy. They are poetically used to reconstruct man in a new image, a fully realized man who is imaginative, through creativity. They are symbolically arranged to appear in a process from a dual world through a prophetic transformation to a new world. This process is both the process of the poem's development and the process of Jerusalem's Reconstruction.

Without Contraries is no progression. Attraction and Repulsion, reason and Energy, Love and Hate, are necessary to Human existence. From these contraries spring what the religious call Good Evil. Good is the passive that obeys Reason. Evil is the active springing from Energy. Good is Heaven. Evil is Hell. (Blake, 1975, p.25)

Blake distinguishes between contraries and negations, the former as existence necessary to each other, and the latter as a condition in which one quality is opposed to the other. These contraries or paradoxes are essentials of human nature, and are paradoxically expressed. These devils are witty and lively and have wise things to say; whereas the angels are dull and in error. Thus, to Blake's viewpoint Heaven is a terrible and dirty place, whereas Hell is a pleasant and clean place. William Blake was strongly opposed to the conventional Christian doctrines. 
Blake proclaims in The Marriage of Heaven and Hell that "If the doors of perception were cleansed every thing would appear to man as it is, infinite"(Blake, 1975, p.20). This reminds us that Joseph Campbell describes Shiva, the Hindu goddess, in whose hand the flame burns out the block of time and opens the way to eternity for our minds. It is just like the burning bush in the Biblical description. God himself appears before man in the column of fire. The Marriage of Heaven and Hell speaks of fire for its transformation of convention and revelation of truth. But transformation seems to Blake a two-way traffic, leading either to the better or to the worse, and at times even shocking. For the cherub with his flaming sword is hereby commanded to leave his guard of the tree of life: and when he does, the whole creation will be consumed and appear infinite and holy, whereas now it appears finite and corrupt. Indeed, the last "Memorable Fancy" ends with the transformation of an Angel into a Devil(www.cyberpat.com):

When he had so spoken, I beheld the Angel, who stretched out his arms embracing the flame of fire, he was consumed and arose as Elijah", and "This Angel, has now become a Devil. (Blake, 1975, p.35)

However, this shocking transformation may function as a negation of the Jerusalem Swedenborg intended to build. As for Blake himself, it might be another matter, because when taking fire as a transforming power, fire can act as a symbol of transformation, inspiration, and spiritual vision. To Blake, this visionary energy can empower imagination and it is God within us to build the New Jerusalem. It is believed that we all have the potential of creating heaven on earth when we find God within us.

But we must remember at the same time that this very Jerusalem he attempts to rebuild is one that is poetic, visionary, and in human mind. This, however, does not reduce Blake as a poet, instead, it helps us to see him as a true poet, because the reconstruction of Jerusalem is what any great poet can do, and no other poets has done it so visionary, so dialectically, and so unified as he has. This alone confirms his significance, as well as his reasons and aim of Jerusalem's reconstruction.

\section{CONCLUSION}

In their treaties and articles, many critics have probed thoroughly into Blake's The Marriage of Heaven and Hell from which they discovered his world and philosophy. Blake's works are not a monotonous and universal system designed by him, but a reflection of a kind of collective experience which he underwent and has been changed through his course of mature. In this sense, much criticism on Blake's religious thoughts tends to be partial.

This thesis draws a conclusion from the discoveries of the specific embodiments of prophecy in The Marriage of Heaven and Hell. Blake predicts the destruction of empire and Jerusalem's reconstruction through the prophetic methods contradiction, vision and imagination. This is the religious empire and the empire of combination of industrial revolution and machines. The machine is the slave of people created, also the tolerate monarch. And we increasingly use it then we become dependent on it. The progress of industrial civilization didn't bring in happiness, and we are still bound, but the empire will be destroyed. Blake's early spirit of revolt is most notably expressed in The Marriage of Heaven and Hell. The contraries in The Marriage of Heaven and Hell are unlike the examples of innocence and experience. Blake wishes them to be understood that he strongly espouses one of his contraries, and firmly rejects the other, and God. He is for energy and against reason, for the Prolific and against the Devourer. He insists on the fact that the world is a product of human labor and imagination.

This not only has historical meanings but also have modern significance. Actually, with the developments of industrial civilization, people feel more and more unhappy. Considerable people begin to realize the fetter of reason and start to seek inner unity and harmony. Most surprisingly, Blake's worries have become reality. And he hopes that human can surpass fetter and boundary and became a unity with infiniteness and eternity.

\section{ACKNOWLEDGMENT}

This project was supported by Teaching Quality Projection of Baoding University ( Jp20090104).

\section{REFERENCES}

[1] Bentley, G.E. (2001). The Stranger from Paradise. New Haven: Yale University Press.

[2] Blake, William. (1975). The Marriage of Heaven and Hell. New York: Oxford University Press.

[3] Blake, William. (1988). William Blake's Selected Poetry. New York: Penguin Group.

[4] Blake, William. (1969). Prophet Against Empire. Princeton: Princeton University Press.

[5] Bloom, H. (1976). Blake's Apocalypse: A study in Poetic Argument. Ithaca: Cornell University.

[6] Bloom, H. (1976). Poetry and Repression. New Haven: Yale University Press.

[7] Broad, William. (2006). The Oracle: Ancient Delphi and the Science Behind its Lost Secrets. New York: Penguin.

[8] Frye, Northrop. (1980). Anatomy of Criticism. Princeton: Princeton University Press.

[9] Glen, Heather. (1983). Vision and Disenchant. Cambridge: Cambridge University Press.

[10] Luk, Charles. (1966). Ch'an and Zen Teaching, Three volumes. London: Rider and Co.

[11] Maxwell, Joe. (1994). PLUS: Seminary Women "Rewrite Their Stories". Christianity Today, January 5, 2012.

[12] Moore, C. A. (1967). The Chinese Mind. Hawaii: University of Hawaii Press.

[13] Qian, Qing. (2006). A History of the 19th Century English Literature. Beijing: Foreign Language Teaching and Research Press.

[14] Wang, Zuoliang. (1991). A History of English Romantic Poetry. Beijing: Renmin Literature Press. 
[15] Zhang, Zhiheng. (1989). William Blake: Prophet of Modernism. Foreign Literature Review, 4,103-106.

[16] http://en.wikipedia.org/wiki/Prophecy (accessed: 03/2014).

[17] http://www.duke.edu (accessed: 03/2014).

[18] http://www.cyberpat.com (accessed: 03/2014).

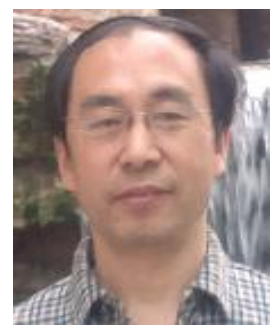

Baoguo Shen was born in 1962 in Hebei, China. He received his Master's degree in Literature and Art from the College of Foreign Languages of Hebei Normal University in Hebei, China in 2004.

$\mathrm{He}$ is currently an Associate Professor and the director of the academic committee of Department of Foreign Languages, Baoding University, China. He has published more than 50 papers and 3 books including Practical English Course( Guangdong, China, Shantou Publishing House, 2006), Study on Fostering College Students' Quality Based on Metacognition (Beijing, China, Foreign Languages in China, 2008), Building Competency Model for Foreign-related Talents Based on SEM (New York, U.S., the Institute of Electrical and Electronics Engineers, 2012). Now His research interests include talent development and cross-culture communication.

Prof. Shen is a member of International Association of Applied Linguistics and a committee member of National Association of Foreign Language Education in China.

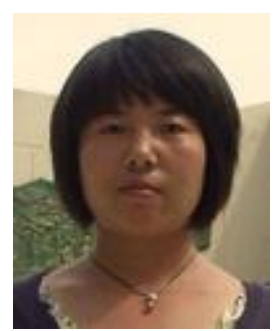

Yinxia Liu was born in 1977 in Hebei, China. She received her Master's degree in Literature and Art from the College of Foreign Languages of Hebei University in Hebei, China in 2006.

She is currently a lecturer in the Department of Foreign Languages, Baoding University, China. She has published the paper: Beauty of The Flowers of Evil-A Study of the Style and Characteristic of Its Writing (Guizhou, China, 2013). Her research interests include language teaching and English literature.

Junxia Yang was born in 1991 in Hebei, China. She received her Bachelor's degree in Literature and Art from the Department of Foreign Languages of Baoding University in Hebei, China in 2008. 